\title{
İslam Felsefesinde İbadetler Ekseninde Dindarlık
}

\section{Religiosity within the Context of Worship in the Islamic Philosophy}

\author{
Emine Taşçi Yıldırım* (])
}

Öz

Genel olarak insanın inandığı dinin emir ve yasaklarını dikkate almak suretiyle oluşturduğu bir yaşam biçimi olarak görülen dindarlığın inanç, ibadet ve ahlak şeklinde üç boyutunun varlığından bahsedilebilir. İslam felsefesi içerisinde doğrudan dindarlık kavramı ele alınmamakla birlikte ibadetlere dair ortaya konulan düşüncelerden hareketle dindarlığa dair bazı ip uçlarına ulaşılabilir. Bu çalışmada, eserleri içerisinde doğrudan ibadetlere dair görüş serd etmiş olan, ilk dönem İslam felsefesinin önde gelen düşünürlerinden bazılarına (Âmîrî, İhvân-ı Safâ, İbn Sînâ, Gazzâlî) yer verilecektir. Bu noktada İbn Sînâ'nın el-Keşf 'an Mâhiyyeti's-Salât ve Hikmeti Teşri'iha li ibn Sînâ adlı eseri başvurulacak kaynakların başında gelmektedir. Bu makalede, dindarlığın ibadet ve ahlak boyutlarının göz ardı edilmemesi gerektiğini ve ahlakî olgunluğa erişmede ibadetlerin nasıl bir fonksiyon icra ettiğini bu düşünürlerin ibadete bakışları üzerinden ortaya koymak amaçlanmaktadır. Bu çerçevede, dindarlığın sadece ibadet boyutunun değil, ahlakî boyutunun da önemli olduğu ve ibadetlerin de bu ahlakî yönü destekleyici olması gerektiği sonucuna varılabilir.

\section{Anahtar Kelimeler}

İslam Felsefesi, Dindarlık, İbadet, Ahlak

\begin{abstract}
Religiosity in general is seen as the way of life formed by taking into account the orders and prohibitions of the religion one believes in. It can be stated that there are three dimensions to religiosity: faith (īmān), worship (ibadah), and morality (akhlaq). The concept of religiosity is not directly addressed in Islamic philosophy. However, some clues about religiosity can be reached based on the ideas put forward regarding worship. In this study, some of the prominent thinkers (Amiri, Ikhwān Al-Ṣafā, Ibn Sīnā, Al-Ghazali) of early Islamic philosophy, who directly expressed their views on worship in their works, will be included. In this sense, the work of Ibn Sīnā called al-Kashf 'an Mâhiyyat al-Salât wa Hikmat Tashri'iha li Ibn Sinā is one of the sources to be consulted. This article aims to reveal that the worship and morality dimensions of religiosity should not be ignored and to reveal the function of worship in reaching moral maturity, through the views of these thinkers on worship. In this framework, it can be concluded that not only worship but also the dimension of morality is important, and that worship should support the morality aspect.
\end{abstract}

\section{Keywords}

Islamic Philosophy, Religiosity, Worship, Morality

* Sorumlu Yazar: Emine Taşçi Yıldırım (Dr. Öğr. Üyesi), Yalova Üniversitesi, İslami İlimler Fakültesi/ Felsefe ve Din Bilimleri Bölümü, Yalova, Türkiye. E-posta: emine.tasci@yalova.edu.tr ORCID: 0000-0001-8520-8545

Att: Emine Taşçi, “islam Felsefesinde İbadetler Ekseninde Dindarlık.” darulfunun ilahiyat 31, 2 (2020): 355-378.

https://doi.org/10.26650/di.2020.31.2.0010 


\section{Extended Summary}

It can be argued that the need to believe has arisen with the existence of man. For this reason, the existence of divine and nontheistic religions that meet this need can also be started with human history. People take into account the orders and prohibitions of the religion they believe in and form a lifestyle within its framework. This way of life is called piety. However, it is not possible to make a definition of religiosity that has clear boundaries and is accepted by everyone. It can be said that religiosity consists of three dimensions: faith, worship, and morality. Faith is a precondition of religiosity. The dimensions of worship and morality on the other hand, show how people reflect the religions in which they believe, on their lives. Differences in these levels reveal various types of religiosity.

Within Islamic thought, Ibn Sīnā offers some clues about religiosity by referring to three types of people: 'arif, zahid, and 'abid. ${ }^{1}$ Based on Al-Ghazali's comments on the differences in religious attitudes and behaviors, it is mentioned that he classified 3 types of religiosity: imitative, scientific (verified), and enjoyed. ${ }^{2}$ Allport, one of the prominent figures in recent studies on religiosity, has made a dual classification of intrinsic-extrinsic religiosity. Batson made a triple classification by adding the quest to these. In current studies, based on Allport's binary classification, by looking at the sincerity and nature of religiosity, a dual classification can also be made of pure-sincere religiosity and ostentatious religiosity. ${ }^{3}$ It can be stated that piety has a determining function in these religious classifications. However, at times it can be mentioned that religiousness is brought to the forefront, and morality is neglected.

It is necessary to evaluate religiosity in terms of faith, worship, and morale. Religiosity, which is based on faith, becomes visible through its worship and morality dimensions. Especially worship is the most obvious example of this visibility. However, when there is no integrity of the meaning or form, worship can only turn into formal movements. When the meaning dimension is grasped, worshipping allows people to reach moral maturity. For this reason, there is an important relationship between the dimensions of worship and morality. In other words, worshipping should support the moral dimension.

In Islamic philosophy, the concept of religiosity is not mentioned directly. However, some clues about it can be obtained from the comments of Islamic philosophers and thinkers about worship. This article aims to reveal that the worship and morality

1 İbn Sînâ, İ̧aretler ve Tenbihler (el-İ̧̧ârât ve't-tenbîhât), çev. Ali Durusoy, Muhittin Macit, ve Ekrem Demirli (İstanbul: Litera Yayınc1l1k, 2005), 182-83.

2 İlhan Topuz, “Gazali'de Dini Tutum ve Davranışlar -Dini Yaşam Biçimleri-”, Marife Dini Araştırmalar Dergisi 11, sy 2 (2011): 172; Gazzâlî, İhyâu ulûmi'd-dîn, çev. Ahmet Serdaroğlu (İstanbul: Bedir Yayınevi, 2002), 3/34-36.

3 Ejder Okumuş, Gösteriş̧̧i Dindarlı (İstanbul: Ark Kitapları, 2005), 42-43. 
dimensions of religiosity should not be ignored and reveal the function of worship in reaching moral maturity, through the views of these thinkers on worship.

Signifying people as believing creatures, Amiri attributes being virtuous to worshipping consciously and sincerely. With this assessment, Amiri clearly reveals the relationship between morality and worship, and he reflects his view of religiosity with his emphasis on sincerity. The "sincere believer" emphasis of the Ikhwān Al-Ṣafā (Brethren of Purity) ${ }^{4}$ makes it possible to argue that the perception of piety/religiosity consists of the integrity of deeds and morality on the basis of faith. Ibn Sīnā, like the Ikhwān Al-Șafā, points to the characteristic of worship as a reminder and as the ensure of the continuity of the Shariah and emphasizes that it enhances morality and purifies the soul. As described by Ibn Sinnā, the "arif (wise) man" who has reached moral maturity and worship without expecting any benefit in return, is a good example of sincere, internalized religiosity.

Al-Ghazali expresses that worship contains divine wisdom for personal and social benefit. According to him, the aim is to purify both the person and the society of material and spiritual dirt in order to help people reach happiness. By emphasizing that worship must be internalized and enhancing morality in order to achieve its purpose, Al-Ghazali, too, points to the distinction between ostentatious religiosity and true religiosity.

As reported by Islamic thinkers, to worship is a must for pure and sincere devotion. They insist on sincere religiosity and materialize it with the profile of the 'arif human. True religiosity can come to life when the trio of faith, worship, and morality come together in a person. While teaching the commandments and prohibitions of religion besides the formal aspects of the worship, a lot of emphasis should be placed on the fact that one of the most important aims is to beautify morality and people should be encouraged to perform worship consciously.

4 İhvân-1 Safâ, İhvân-ı Safâ Risâleleri, çev. Abdullah Kahraman vd. (İstanbul: Ayrıntı Yayınları, 2012), 1/236; İhvân-1 Safâ, Resâilü İhvâni's-Safâ ve Hullâni'l-Vefâ (Kum: Mektebü'l-İ'lami'lİslamiyye, 2000), 1/346. 


\section{İslam Felsefesinde İbadetler Ekseninde Dindarlık}

\section{Giriş}

İnanma ihtiyacı, insanın varoluşuyla eş zamanlı olarak mevcuttur denilebilir. $\mathrm{Bu}$ anlamda inanma ihtiyacına cevap veren dinlerin varlığ da insanlık tarihiyle beraber başlatılmaktadır. Dünya üzerinde ilahi olan ve olmayan birçok din mevcuttur. $\mathrm{Bu}$ dinlerin, kendisine inanan ve dindar diye nitelenen insanlara yönelik bazı emir ve yasakları vardır. Bunları ibadet ve ahlak olmak üzere iki kategoride toplamak mümkündür. İnsanların inandıkları dinleri hayatlarına yansıtma düzeylerine bağlı olarak farklı dindar insan profilleri ortaya çıkmaktadır.

Günümüzde ortaya çıkan farklı dindarlık tezahürleri, dindarlık ile ibadet arasındaki bağlantının nasıl olması gerektiğini, özü kavranmaksızın şekilsel olarak yerine getirilen ibadetlerle sınırlandırılmış bir dindarlık anlayışının eksik yönlerinin neler olduğunu araştırmayı gerekli kılmaktadır. Değişken ve istikrarsız bir tabiata sahip olan insanın, dengeli ve tutarlı karaktere kavuşmasını sağlamak, ilahi hakikatle olan ilişkisini sürekli hale getirmek için sistemli davranış ve uygulama düzeni gerekmektedir. Bu anlamda ibadetlerin, kişilik ve karaktere etki edip onları düzenleyen ve dengeleyen bir sistem olduğundan bahsedilebilir. Öngörülmüş, değişmez asli unsurlardan oluşan bir şekil ve kalıbı olan ibadetlerin birçoğu, sembolik bir tarzda düzenlenmekle birlikte derin manalar içermektedir. Mananın başka bir deyişle özün kavranmasında ibadetlerin şekli etkilidir. ${ }^{5}$ Ancak ibadetlerde şekil ve mana bütünlüğü sağlanmadığında "Vay o namaz kılanların haline ki: Onlar kıldıkları namazdan gafildirler." ${ }^{\prime \prime}$ ayetinde dikkat çekilen durum ortaya çıkmaktadır. Nitekim İlhami Güler'in vicdansız dindarlık başlığı altında yaptığı şu değerlendirmesi de dikkat çekicidir: "İbadetler, "antreman” yapmaya benzer; amaç, insanı yarışmaya (salih amel: adalet/dürüstlük/hakkaniyet-merhamet) hazırlamaktır. Günümüzde Hac-Umre ziyareti, "miting” zevkine-turizme; Namaz, Allah'a karşı şükran ve saygıyı ifade etme ve insanı kötülüklerden alıkoymadan, kendinde/kendisi için "sevap/kontür aracı"na; Oruç ise, iftar sofrasındaki nefis yemeklere saldırma işlevine/şehvetine dönüşmüştür." kişilik ve karakteri üzerinde düzenleyici ve dengeleyici, ahlakını güzelleştirici bir etkisi olması gereken ibadetlerin, manası kavranmaksızın sadece şekilsel olarak yapıldığını gösteren çarpıcı bir örnektir.

5 Hayati Hökelekli, Din Psikolojisi (Ankara: Türkiye Diyanet Vakfı Yayınları, 2004), 234-235,241.

6 Mâ'ûn 107/4-5.

7 İlhami Güler, “'Vicdansız Dindarlık’ Olarak Güncel Müslümanlık”, İslami Analiz, erişim 20 Şubat 2020, http://www.islamianaliz.com/m/3500/vicdansiz-dindarlik-olarak-guncel-muslumanlik. 
"(Ey Muhammed!) Kitaptan sana vahyolunanı oku, namazı da dosdoğru k11. Muhakkak ki namaz, insanı hayâsızlıktan ve kötülükten alıkoyar. Allah'ı anmak (olan namaz) elbette en büyük ibadettir. Allah, yaptıklarınızı bilir." ayetinde bahsedilen ve ibadetlerin en büyüğü olan namazın insanın ahlakını güzelleştirme fonksiyonu açıkça zikredilmektedir. $\mathrm{Bu}$ anlamda namaz, insanın nefsani duygulardan arınıp kendi özünü keşfetmesini sağlamalıdır. Ancak kendisini dindar olarak ifade eden birçok insan, kıldığı namazla şekilselcilikten kurtulmak suretiyle namazını içselleştirmeyi başarıp kendi benliğinde böyle bir dönüşümü gerçekleştirememektedir. Bu sebeple ibadetlerin ahlaki olgunluğa ulaştırıcı vasıflarının tekrar hatırlanması ve hatırlatılmasının gerekliliği açık bir şekilde ortaya çıkmaktadır.

$\mathrm{Bu}$ çalışmayla önde gelen İslam düşünürlerinin ibadetlerin gayesi ve ahlaki olgunlaşmadaki fonksiyonlarına dair görüşleri ele alınacaktır. Bu görüşlerden hareketle ibadet-ahlak ilişkisi üzerinden dindarlığa ilişkin genel bakışlarını tespit etmek amaçlanmaktadır. Onların ibadetler üzerinden ortaya koydukları dindar insan profiline dair düşüncelerini günümüze aktarmak önem arz etmektedir ki bu görüşlerin, gösterişçi ve şekilsel dindarlıktan kurtulma konusunda yol gösterici olacağı düşünülmektedir.

İlgili literatür tarandığında dindarlıkla ilgili son dönemde farklı alanlarda birçok çalışma yapılımıştır. ${ }^{9} \mathrm{Bu}$ çalışmalar arasında dindarlık pek çok açıdan ele alınmakla birlikte İslam düşünürlerinin ibadetler üzerinden dindarlığa nasıl baktıklarına ilişkin bir çalışmaya rastlanmamıştır. Bu çalışmada ilk olarak günümüzdeki dindarlık kavramı, boyutları ve çeşitleri konusunda bilgi verilecektir. Ardından önde gelen bazı İslam düşünürlerinin ibadetlere ilişkin görüşlerinden yola çıkılarak nasıl bir dindar insan profili çizdikleri ve dindarlık-ibadet-ahlak ilişkisine dair görüşleri ortaya konulmaya çalışılacaktır. İslam felsefesi çok geniş bir alan olduğu için çalışma,

8 Ankebut 29/45.

9 Bunlardan bazıları şunlardır: Necdet Subaşı, “Türk(iye) Dindarlığı: Yeni Tipolojiler”, İslâmiyât V, sy 4 (2002): 17-40; Ali Ulvi Mehmedoğlu, Kişilik ve Dindarlık (Dindarlık Düzeyi ile Kişilik Özellikleri Arasındaki İlişki Üzerine Bir Araştırma) (İstanbul: Değerler Eğitim Merkezi Yayınları, 2004); Ejder Okumuş, Gösterişşi Dindarlık (İstanbul: Ark Kitapları, 2005); Asım Yapıcı, Ruh Sağlı̆̆ ve Din: Psiko-sosyal Uyum ve Dindarlık (Adana: Karahan Kitabevi, 2007); Mustafa Öztürk, "Bilgi-Ahlâk-Dindarlık", Diyanet Aylık Dergi, sy Ağustos (2007): 5-7; Ali Ayten, Empati ve Din: Türkiye'de Yardımlaşma ve Dindarlık Üzerine Psiko-sosyal Bir Araştırma (İstanbul: İz Yayınc1lık, 2010); İbrahim Gürses, Dindarlık ve Kişilik (Bursa: Emin Yayınları, 2010); Hasan Kayıklık, Din Psikolojisi: Bireysel Dindarlı Üzerine (Adana: Karahan Yayınlar1, 2011); Zafer Cirhinlioğlu, Üzeyir Ok, ve Fatma Gül Cirhinlioğlu, Dindarlık Ruh Sağlığ ve Modernite (Ankara: Nobel Akademik Yayıncılık, 2013); Yahya Turan, Kişilik ve Dindarlık (İstanbul: Ensar Neşriyat, 2017); Fatma Baynal, “Türkiye’de Dindarlık Üzerine Kullanılan Ölçeklere Yönelik Sorunlar ve Öneriler”, içinde Din Psikolojisi Güncel Durum Analizi (Ankara: Nobel Akademik Yayıncılık, 2020), 263-86. 
ibadetlere dair doğrudan değerlendirmelerde bulunmuş olan Âmirî (ö. 381/992), İhvân-1 Safâ, İbn Sînâ (ö. 428/1037) ve Gazzâlî (ö. 505/1111)ile sınırlandırılmıştır.

\section{Dindarlık Kavramı}

Dindarlık kavramının herkes tarafından kabul görmüş, sınırları belli olan bir tanımını yapmak mümkün görünmemektedir. Bölgeden bölgeye, kültürden kültüre, hatta kişiden kişiye değişen bir kavram olarak dindarlık, sözlükte, "dindar olma durumu, bir kimsenin dini emirlere riayet etmesi ve o doğrultuda yaşaması durumu, Allah ile kul arasında olan iş, ibadet ve kişinin dindarl $1 \mathrm{~g} 1,{ }^{10}$ dini emirlere hakkıyla uymak $^{11}$ " şeklinde tanımlanmaktadır. Ayrıca bu kavram, kişinin günlük hayatında dinin önemine işaret etmekle birlikte, ona bağlanma ve inanma derecesini de göstermektedir. ${ }^{12}$ Daha genel bir tanımda ise dindarlık, yaşanan din $^{13}$ veya dinin sübjektif ifadesi olarak görülmekte ve herhangi bir dinsel yapıya bağlılığı ifade etme manasında kullanılmaktadır. ${ }^{14}$ Başka bir deyişle dindarlığı, kişinin dinle kurduğu bağl1lı̆̆ın sübjektif bir ifadesi ve öznel bir deneyim olarak görmek mümkündür. ${ }^{15}$ Özetle, ilahi bir varlığa bağlı olma bilinci olarak da görülen dindarlığ teşkil eden bağl1lık, kişinin ahlaki ve ibadetlerle ilgili davranışlara odaklanmasını sağlamak suretiyle bireyin yaşantı, inanç ve kişiliği üzerinde etkili olmaktadır. ${ }^{16}$

İnanç, din ve dindarlığı bir arada düşünüp tarif edecek olursak inanç, Yüce Varlık ile insan arasındaki manevi bağlantıdır. Din, bu bağlantının oluşturduğu ilişkiler bütününü ifade etmektedir. Dindarlık ise bütün bunların bireysel hayata yansıyan yönünü teşkil etmektedir. ${ }^{17} \mathrm{Bu}$ açıklamadan yola çıkarak dindarlığı, din ve inancın birlikteliğinin bireyde somutlaşmış hali olarak görmek mümkündür.

Çok yönlü bir kavram olması hasebiyle dindarlık, çeşitli ilmi disiplinler tarafından farklı bakış açıları ekseninde irdelenmiştir. Bunlardan bazılarının dindarlı̆̆ çerçeveden inceledikleri belirtilmektedir: "Din bilimleri dindarlı̆̆ı, inanç esasları

10 Ali Seyyar, Insan ve Toplum Bilimleri Terimleri (Ansiklopedik Sosyal Bilimler Sözlüğü) (İstanbul: Değişim Yayınları, 2007), 241-42.

11 Ahmet Nedim Serinsu, ed., Dini Terimler Sözlüğ̈̈ (Ankara: Milli Eğitim Bakanlığı Yayınları, 2009), 61.

12 Mehmet Ali Kirman, Din Sosyolojisi Sözlüğ̈̈ (Adana: Karahan Kitabevi, 2016), 81.

13 Enver Günay, "Dindarlığın Sosyolojisi”, içinde Dindarlığın Sosyo-Psikolojisi, ed. Enver Günay ve Celaleddin Çelik (Adana: Karahan Kitabevi, 2006), 22.

14 Şinasi Gündüz, Din ve İnanç Sözlüğ̈̈ (Ankara: Vadi Yayınları, 1998), 96.

15 Subaşı, “Türk(iye) Dindarlığı”, 24; Ayten, Empati ve Din, 130.

16 Cirhinlioğlu, Ok, ve Cirhinlioğlu, Dindarlık Ruh Sağlı̆̆

17 Yapıcı, Ruh Sağlı̆̆l ve Din, 23. 
merkezinden açıklarken; psikoloji, birey yaşantılarına etkisi, dini bağlılığın boyutları, kutsallık ve dini saygı bağlamında; sosyoloji ise, dinin toplum hayatındaki işlevi ve dini kurum ve cemaatlere bağl11ık çerçevesinde ele almaktadır." ${ }^{18}$ Özetle söylemek gerekirse dindarlık, her bilim dalının genel yaklaşımı çerçevesinde farklı yönleriyle ortaya konulmaktadır.

\section{Dindarlığın Boyutları}

Dindarlığın boyutları, aslında dini hayatın boyutları olarak ele alınabilir. Nitekim günlük hayatta dinin görünen ve görünmeyen, başka bir deyişle de soyut ve somut olmak üzere genel olarak iki boyutundan bahsetmek mümkündür. ${ }^{19}$ İslam kültüründe dindarlık, dinin ilkelerine inanmak anlamındaki iman, inanılan ilkelerin birey-Allah ilişkisi alanını oluşturan ibadet ve birey-öteki ilişkisi manasındaki ahlak şeklinde üç boyuttan teşekkül etmektedir. ${ }^{20}$ İman, dindarlığın olmazsa olmazları arasında yer almaktadır. İbadet ve ahlak imandan sonra gelmektedir. Ancak bazen dindarlıkta ibadetler ön plana çıkartılıp ahlakın ihmal edildiğinden bahsedilebilir.

Müslüman denilince ilk akla gelen şeylerin başında dinde samimiyet ve dindarlık gelmektedir. Bunun alt boyutlarını ise inançlı olmanın ardından ibadetlere devamlılık takip etmektedir. Daha sonrasında ise bunun ahlaki alan başta olmak üzere dinin bireysel ve sosyal hayatta etkisinin hissedilmesi şeklinde kavramsallaştırıldığı görülmektedir. ${ }^{21}$

Dindarlığa ilişkin bir diğer boyut da ahlaktır. Din ve dindarlık, ahlaki değerlerin korunmasında ve toplumsal huzurun inşasında önemli bir fonksiyon icra etmektedir. ${ }^{22}$ Dindarlığın toplumsal davranışlar üzerinde, insanın suç işleme ve dinin kötü gördüğü davranışlardan uzak durmada etkisinin olduğu bir gerçektir. Nitekim yapılan birçok araştırmada dindarlık ile suç işleme arasında negatif bir ilişkinin; yardımlaşma ve paylaşma gibi davranışlarla pozitif bir ilişkinin varlığına ulaşılmışıtır. ${ }^{23}$

Kısacası, dindarlığı hem inanç hem ibadet hem de ahlaki boyutuyla -davranış boyutu da denebilir- değerlendirmek gerekmektedir. İnancın ana zemini oluşturduğu dindarlık, ibadet ve ahlak boyutuyla görünür hale gelmektedir. Özellikle ibadetler, bu görünürlüğün en bariz örnekleridir. Ancak mana ve şekil bütünlüğü sağlanmadığında

18 Turan, Kişilik ve Dindarlık, 108.

19 Kayıklık, Bireysel Dindarlı Üzerine, 192.

20 Kayıklık, Bireysel Dindarlı Üzerine, 199.

21 Yapıcı, Ruh Să̆lığı ve Din, 33.

22 Yapıcı, Ruh Să̆lığı ve Din, 58.

23 Ayten, Empati ve Din, 99. 
ibadetler, sadece şekilsel hareketlere dönüşebilmektedir. Mana boyutu kavrandığında ise ibadetler, insanın ahlakî bir olgunluğa erişmesini sağlamaktadır. Bu sebeple ibadet ve ahlak boyutu arasında önemli bir ilişki mevcuttur. Başka bir deyişle ibadetler, ahlaki boyutu destekleyici nitelikte olmalıdır. Buna göre dindarlığın birbiriyle bağlantılı üç boyutu olduğunu söyleyebiliriz.

\section{Dindarlık Türleri, Dindarlık ve İbadet-Ahlak İlişkisi}

Farklı bakış açıları ekseninde çeşitli dindarlık türlerinden bahsedilmektedir. ${ }^{24}$ Dindarlık sınıflamalarının özsel ve nitelendirici anlayış ekseninde şekillendiği söylenebilir. ${ }^{25}$ İslam felsefesinde açık bir şekilde yapılmış dindarlık sınıflamasından söz etmek pek mümkün görünmemektedir. Ancak İbn Sînâ, bir dindarlık sınıflaması yapmamakla beraber şu tür insan tipine işaret etmektedir:

\footnotetext{
"Dünya metaından ve güzelliklerinden yüz çeviren kimseye zahit; namaz k1lmak, oruç tutmak gibi ibadetlere devam eden kimseye abid; Hakkın nurunun sürekli sırrında parlamasını dileyerek, düşüncesiyle ceberrut kutsiyetine yönelene arif adı özgü kılınır. Bazen bunların bir kısmı diğeriyle birleşir. Arif olmayan nezdinde züht bir tür muameledir: Adeta zahit, dünya meta1 karşılığında ahiret metaını satın almaktadır. Arif nezdinde züht, sırrını Haktan meşgul eden şeyden arındırmak ve Haktan ve ibadetten başka her şeye karşı büyüklenmektir. Arif olmayan nezdinde ise züht, yine bir çeşit muameledir. Adeta o, dünyada ahirette alacağı bir ücret karışlığında amel eder ki o da ahirette alacağı, ödül ve sevaptır."26
}

İbn Sînâ'nın yukarıda bahsettiği üç insan profili yani arif, zahid, abid ayrımı, doğrudan dindarlık ibaresi kullanılmasa bile İslam felsefesinde dindarlığa dair bazı unsurların bulunabileceği şeklinde yorumlanabilir.

Önemli İslam düşünürlerinden Gazzâlî’nin de dini tutum ve davranışlardaki farklılıklara dair yorumlarından yola çıkarak taklidi, ilmi (tahkiki) ve zevk alınan dindarlık şeklinde üçlü bir tasnif yaptığından bahsedilmektedir. ${ }^{27}$ İbn Sînâ’nın dindar insan tipleri ve Gazzâlî’nin düşünceleri üzerinden bir çıkarım sonucu oluşturulan bu sınıflandırma İslam düşünürlerinin metinlerinde günümüzdeki dindarlık sınıflamalarını çağrıştırıcı ibarelere rastlamanın mümkün olduğunu göstermektedir. Bu sebeple İslam düşünürlerinin ibadetlere bakışları ekseninde

24 Detaylı bilgi için bk. Kemaleddin Taş, "Dindarlığın Kriterleri Üzerine Tipolojik Bir Araştırma", içinde Dindarlı̆̆ın Sosyo-Psikolojisi, ed. Enver Günay ve Celaleddin Çelik (Adana: Karahan Kitabevi, 2006), 179.

25 Mehmedoğlu, Kişilik ve Dindarlık, 38; Yapıcı, Ruh Sağllğ l ve Din, 21.

26 İbn Sînâ, İşaretler ve Tenbihler (el-İşârât ve't-tenbîhât), çev. Ali Durusoy, Muhittin Macit, ve Ekrem Demirli (İstanbul: Litera Yayınc1lık, 2005), 182-83.

27 İlhan Topuz, "Gazali'de Dini Tutum ve Davranışlar -Dini Yaşam Biçimleri-", Marife Dini Araştırmalar Dergisi 11, sy 2 (2011): 172; Gazzâlî, İhyâu ulûmi'd-dîn, çev. Ahmet Serdaroğlu (İstanbul: Bedir Yayınevi, 2002), 3: 34-36. 
nasıl bir dindar insan profili çizdiklerinin daha net şekilde ortaya konulması için günümüzde yapılan bazı dindarlık sınıflamalarından bahsetmek faydalı olacaktır.

İlgili literatüre bakıldığında Allport ve Batson tarafından yapılan dindarlık sınıflandırmalarının ön plana çıktığı söylenebilir. Allport, dini kişilik yönünden insanları sınıflandırmak suretiyle iç-güdümlü (intrinsic) ve dış-güdümlü (extrinsic) şeklinde bir dindarlıktan bahsetmiştir. ${ }^{28}$ İ̧-güdümlü dindarlık, hayatının merkezine dini yerleştiren ve bütün düşüncelerin üstünde tuttuğu dine tam bir teslimiyeti içeren bir dindarlık olarak tanımlanmaktadır. Dış güdümlü dindarlığa gelince tehlike anında kişisel emniyeti ön planda tutan, faydacı ve dini olmayan amaçlara yönelebilen, içgüdümlü dindarlığın tam tersini teşkil eden bir dindarlık türü olarak görülmektedir. ${ }^{29}$ Genel olarak söylemek gerekirse birey, iç-güdümlü dindarlıkta dini yaşarken; dışgüdümlü dindarlıkta dini kendi amaçları (ilgi çekme, güvenlik, teselli, statü elde etme, sosyalleşme vb.) için kullanmaktadır. ${ }^{30}$ Batson tarafindan bu dindarlık türlerine, sorgulayıcı dini yönelim yani dindarlık eklenmiştir. ${ }^{31}$ Batsonun bu eklemesiyle üçe çıkan dindarlık türleri, Gazzâlı’’nin üçlü sınıflandırmasını çağrıştırmaktadır ki zevk alınan dindarlığın iç güdümlü dindarlığa; taklidi dindarlığın dış güdümlü dindarlığa ve ilmi (tahkiki) dindarlığın da sorgulayıcı dindarlığa tekabül ettiği söylenebilir.

Dış-güdümlü dindarlıkta, dua bir nevi Tanrı'nın gücünü kendi yararı doğrultusunda kullanma amacıyla yapılmakta ve bu tarz dindarlar ancak başları sıkıştığında yüce varlığa sığınma ihtiyacı hissetmektedirler. ${ }^{32}$ Nitekim Kur'an'ın “İnsana bir sikıntı dokundu mu, gerek yan üstü yatarken, gerek otururken, gerekse ayakta iken (her hâlinde bu sıkıntıdan kurtulmak için) bize dua eder. Ama biz onun bu sıkıntısını ondan kaldırdık mı, sanki kendisine dokunan bir sıkıntı için bize hiç yalvarmamış gibi geçer gider..." ${ }^{33}$ ayetiyle bu tarz bir dindarlığa işaret ettiği söylenebilir. Bu aynı zamanda sadece cehennemden kurtulmak üzere ibadet eden ya da sadece cennete gitmek üzere çalışan dindar insanı hatırlatmaktadır. İç-güdümlü dindarlıkta ise dua, aşkın bir varlıkla kurulan bir ilişki olarak görülmekte ve bir menfaat beklenilerek yapılmamaktadır. ${ }^{34}$

28 Mehmedoğlu, Kişilik ve Dindarlık, 40; Gürses, Dindarlık ve Kişilik, 25. Bu dindarlık tanımlaması içsel ve dışsal dindarlık (Cirhinlioğlu, Ok, ve Cirhinlioğlu, Dindarlık Ruh Sağglığ 12.) ya da derûnî ve dış beklentiye yönelik dindarlık şeklinde çevrildiği görülmektedir (Kayıklık, Bireysel Dindarlı Üzerine, 197.).

29 Mehmedoğlu, Kişilik ve Dindarlık, 40-41.

30 Kayıklı, Bireysel Dindarlık Üzerine, 197.

31 Ayten, Empati ve Din, 104.

32 Gürses, Dindarlık ve Kişilik, 28.

33 Yunus 10/12. Ayrica bk. Zümer 39/8, Rum 30/33, İsra 17/67.

34 Gürses, Dindarlık ve Kişilik, 28. 
İbadetler merkeze alınarak, dinin talep ettiği fiillerin yerine getirildiği dindarlık ve inancın davranışlara dönüşmediği dindarlık şeklinde genel bir sınıflama yapılmaktadır. Bunların da kendi içerisinde alt grupları mevcuttur. ${ }^{35} \mathrm{Bu}$ bağlamda Müslüman Türk toplumunda, "ateşli dindarlar, alaca dindarlar, mevsimlik dindarlar, beynamaz dindarlar ve ilgisiz dindarlar" ${ }^{\prime 36}$ olmak üzere beşli bir sınıflamaya gidilmektedir.

Güncel çalışmalarda Allport'un yaptığı ikili sınıflamadan hareketle dindarlığın içtenliğine, niteliğine ve samimi olup olmadığına bakılmak suretiyle ihlaslı-samîmi dindarlık ve gösteriş̧̧i dindarlık şeklinde ikili bir tasnif de yapılmaktadır. ${ }^{37}$ Çalışmanın amaçlarından biri olan dindarlıktaki ibadet ve ahlak boyutunun birlikteliğinin ne kadar önemli olduğunu ortaya koymak açısından bu sınıflandırma detaylı bir şekilde ele alınacaktır. Nitekim gösterişçi dindarlık tipi, ahlakî olgunluğa erişemeyen insanlarda görülebilecek bir tür olarak yorumlanabilir.

Gösterişçi dindarlı̆̆ın altında bazı psikolojik, sosyolojik ve siyasal nedenler yatmaktadır. Psikolojik nedenleri şu şekilde sıralamak mümkündür: Kişilik zaafi ve bozukluğu, kalp hastalığı, tatminsizlik, çıkar beklentisi, güvensizlik ve kendini gerçekleştirememe, böbürlenme, kibir ve gurur, şöhret, itibar, makam, toplumsal onur ve statü kazanma arzusu, özenti, öykünme ve taklit, ihlas eksikliği, övülme arzusu, haset, dünya sevgisi ve cimrilik, kendini beğenme ve bencillik, galibiyet arzusu, şüphe ve tereddüt, karakter bozukluğu, savunma mekanizmaları, paranoya, çelişki, korku ve korkaklık, günahkarlık ve suçluluk duygusu, aşağılık kompleksi, üstünlük kompleksi, kanıtlama kompleksi, bilinçsizlik. ${ }^{38}$ Bu bahsedilen nedenler aslında dindarlığın gereklerinin yerine getirilmemesini ve ahlakî olgunlaşmanın sağlanmamasını beraberinde getirmektedir.

Gösterişçi dindarlığın sosyolojik nedenleri olarak sosyo-kültürel yapı, imaj ve gösteri, moda ve kıyafet, biçime ve niceliğe önem verme, farklılıkları kabul etme, bask1, kınama ve korku, dışlanma, tutuculuk, ailevi nedenler, meslek seçimi, ekonomik sebepler, toplumsal kabul görme, meşruiyet, kimlik bunalımı, damgalanma, ödül ve ceza, savunucu iletişim, manipülasyon, sosyal kontrolün etkisizliği, güvensiz ortam, sosyal tabakalar ve statü sayılabilir. ${ }^{39}$

Gösterişçi dindarlığı ortaya çıkaran bazı etmenler vardır. Bu etmenler, siyasal meşruiyet, oy kazanma arzusu, inanç ve düşünce özgürlüğünün bulunmaması,

35 Yapıcı, Ruh Sağlı̆̆l ve Din, 33.

36 Yapıcı, Ruh Sağlı̆̆l ve Din, 34.

37 Okumuş, Gösteriş̧̧i Dindarlık, 42-43.

38 Okumuş, Gösterişşi Dindarlık, 110-52.

39 Okumuş, Gösterişçi Dindarlık, 154-89. 
siyasal bask1, siyasal nüfuz, kötü eğitim, egemen olanın yanında görünme kaygısı, liderlik veya siyasal statü kaybına maruz kalma korkusu, siyasi manipülasyon şeklinde ele alınabilir. ${ }^{40}$

Yukarıda zikredilen nedenlerin doğurduğu sonuçlara bakılacak olursa gösterişçi dindar profilleri toplumun din algısına zarar vermektedir. Nitekim psikolojik, sosyolojik ve siyasal nedenlere bağlı olarak meydana gelen gösteriş̧̧i dindarlık, iki yüzlü-çifte kişilikli insanların ve yapay ilişkilerin ortaya çıkışına zemin hazırlamaktadır. Bununla birlikte güven bunalımı, anomi ve yabancılaşma, sapma, çatışma, gösterişçi tüketimin artışı, nifak, fitne, fesat ve fısk gibi toplumsal sorunlar doğurmaktadır. Ayrıca bu amellerin iptali, bilgisizliğin artışı, dünyevileşme gibi sorunları da beraberinde getirmektedir. ${ }^{41} \mathrm{Bu}$ zararlı sonuçları düşünüldüğünde dindarlığın ibadet boyutu yanında ahlakî boyutunun kesinlikle göz ardı edilmemesinin gerekliliği de gün yüzüne çıkmaktadır.

Allah'a karşı bir borç ve vazife olarak algılanan ibadetler, insandaki sorumluluk duygusunun gelişimini sağlamaktadır. Ahlaki davranışlar ise sorumluluk şuuruyla yerine getirilmelidir. Bu bağlamda ibadetler, kişinin ahlaki tabiatının gelişiminde önemli bir rol icra etmektedir. ${ }^{42}$ Nitekim bu anlamda içerisinde eylem, hareket ve etkinliği barındıran ibadetler, birbirini tamamlayıcı olan ve kişilik özelliklerinin gelişmesini sağlayan bir eğitim programı olarak da değerlendirilebilir. ${ }^{43}$

Dinî emir ve yasakların hikmetler içerdiği bir gerçektir. Bu hikmetler arasında insanı kötülüklerden uzak tutma ve onun şerefini korumak suretiyle ahlakî olgunluğa eriştirme zikredilebilir. İbadetler de bu anlamda hem imanı besleme hem de ahlakı yüceltme fonksiyonlarını gerçekleştirmede bir araç olarak görülebilir. ${ }^{44} \mathrm{Bu}$ bağlamda dindarlığın içerisinde bulunması gereken unsurlar iman temelinde bilgi ve ahlaktır. Ahlakî boyutu ihmal edilmiş bir dindarlık şekilsel olarak dini vecibeleri yerine getirmek anlamına gelmekte ve samimiyetten uzak olmaktadır. Buna bilgisizlik de eklenince bu tarz bir dindarlık ancak taassup üretici bir vasfa haizdir. ${ }^{45}$ İbadetleriyle övünüp ahlakî zafiyet içerisinde olan insanlar Allah ile olan ilişkilerindeki bu eksiklikleri ibadetle kapatarak gösterme eğilimindedirler. Bu durum hem onlara hem yaşadıkları bu dindarlık şekliyle temsil ettikleri dinin başkaları tarafından

40 Okumuş, Gösteriş̧̧i Dindarlık, 236-47.

41 Okumuş, Gösterişçi Dindarlık, 251-60.

42 Hökelekli, Din Psikolojisi, 243.

43 Hökelekli, Din Psikolojisi, 249.

44 Enver Uysal, "Dindarlığın Ahlâkî Temeli Üzerine Bazı Düşünceler”, Uludağ Üniversitesi İlahiyat Fakültesi Dergisi 14, sy 1 (2005): 44.

45 Öztürk, "Bilgi-Ahlâk-Dindarlık", 5,7. 
yanlış anlaşılmasına sebebiyet vermektedir. Kısacası, ahlak yönü göz ardı edilen bir dindarlığın kişiye ve topluma olumlu bir yönde etkisinin varlığından söz etmek zor görünmektedir. Aşağıda yer verilecek olan İslam düşünürlerinin ahlak temelli dindarlık vurgularında ibadet-ahlak ilişkisine açıklık getirilecektir.

\section{İslam Düşünürlerinin İbadetlere Bakışları ve Dindarlık Algıları}

Tanrı-insan ilişkisi İslam felsefesinin üzerinde durduğu önemli konulardan biridir. Bu ilişkinin bir boyutunu yansıtan ve İslam felsefesinin özgün yanlarından olan nübüvvet teorisi içerisinde filozoflar tarafından peygamberliğin lüzumu, peygamberlerin örnek oluşu ve ibadetlerin neden gerekli olduğu irdelenmiştir. İslam düşünürlerinin bu konulara dair söylemlerinde dindarlığa, ibadet-ahlak ilişkisine dair bazı açıklamaların bulunduğu söylenebilir. Ayrıca onların, siyaset felsefesi ve ahlaka dair düşünceleri içerisinde özellikle erdemli insan profillerinden yola çıkarak dolaylı olarak ihlaslı-samimi bir dindarlığın nasıllığına dair ipuçları bulmak mümkün görünmektedir. Ancak bu bölümde, İslam düşünürlerinin çok geniş bir literatür oluşturan ahlak görüşlerinden ziyade, onların ibadetlere yönelik fikirleri üzerinden ortaya koyduklarını düşündüğümüz dindarlık algıları açıklanmaya çalışılacaktır.

İlk İslam filozofu olarak tanınan Kindî’nin ibadetlere ilişkin net bir açıklamasına rastlanmamaktadır. Fârâbî' ye gelince, onun da ibadetlere ilişkin doğrudan bir değerlendirmesi bulunmamakla birlikte ahlakî yatkınlık vurgusundan kısaca bahsetmek faydalı olacaktır. Doğası gereği bazı eğilimler ve yeteneklere sahip olan insanın ahlakî gelişime yönelik bir yatkınlığı vardır. Bunu Fârâbî, doğal erdem/ahlakî erdem olarak ifade etmekte ve doğuştan yatkın olduğu erdemleri bilfiil gerçekleştirmek suretiyle adet haline getiren kimseyi ise ilâhî insan olarak nitelendirdiği görülmektedir. ${ }^{46}$ Enver Uysal, Fârâbî'nin bahsettiği bu ilâhî insanın, erdemleri gerçekleştirmede dinin rolü dikkate alındığında dindar insan olarak algılanabileceğini ve buradan da yola çıkarak dindarlığın temelinde ilk olarak doğal yatkınlık, daha sonra ise ahlakî yetkinliğin bulunduğunun söylenebileceğini belirtmektedir. ${ }^{47} \mathrm{Bu}$ bağlamda Fârâbî’nin ilâhî insan nitelemesi ve peygamberfilozof profili üzerine inşa ettiği erdemli şehrin reisiyle hakikî dindar profiline dair ipuçları sunduğunu söylemek mümkündür.

Fârâbî'den sonra yetişmiş bir diğer İ̉lam filozofu Âmirî, insanın doğası gereği dini bir canlı olduğu (el-insanu dîniyyün bi’tab') görüşünde olup dini kural ve

46 Uysal, "Dindarlığın Ahlâkî Temeli”, 48-50; Fârâbî, "Mutluluğu Kazanma (Tahsilu's-Sa'ade)", içinde Farabi'nin Ü̧̧ Eseri, çev. Hüseyin Atay (İstanbul: Morpa Kültür Yayınları, 2008), 44; Fârâbî, “Fusûlü'l-medenî (Siyaset Felsefesine Dair Görüşler)", içinde Fârâbî'nin İki Eseri, çev. Hanifi Özcan (İstanbul: Marmara Üniversitesi İlahiyat Fakültesi Vakf1, 2005), 54-55. 
şer'î modellerin, nefis ve bedenden müteşekkil olan insanın aklî nefsini yok olacak şeylerden baki olana yönlendirme, zulmetten nura çıkarma, hayvanlık tabiatından kurtarıp hikmete ulaştırma, sûflî alemden ulvî aleme yükseltme fonksiyonunun olduğunu belirtmektedir. ${ }^{48}$ Dini kurallara dair bu düşüncesinin yanı sıra filozof, bir kimsenin mutlak erdemli diye nitelenebilmesi için hikmeti elde etmesi ve ihlasli ibadeti alışkanlık haline getirmesi gerektiğini düşünmektedir. ${ }^{49}$ Erdemli olmak ile ihlaslı, gösterişten uzak bir şekilde ibadetleri yerine getirmenin gerekliliği Âmirî tarafından açıkça dile getirilmekte ve gerektiği gibi yerine getirilen ibadetlerin ahlaklı olma yolunda insan üzerindeki etkisi de burada açığa çıkmaktadır.

İnsanın kötü bir fiili gerçekleştirmesinin nefsini ihmal etmeye sebep olduğunu, bunun da onu daha kötü fiillere yöneltebileceğine dikkati çeken Âmirî, bu durumda kişinin aşırı pervasız olup dini değerlere, kutsala hürmet göstermemeye başlayacağını belirtmektedir. Böyle bir durum içerisinde bulunan kimsenin nefsi kirlendiğinden dolayı namaz, oruç vb. ibadetler ona yarar sağlamayacaktır. Bunun sebebi, kişi bu ibadetleri sürekli olarak yerine getirse bile ibadetler, tabiî bir fiil ve alışkanlık, gösteriş, şöhret, yalan, şekil ve merasimden öteye geçememektedir. Bu yüzden de Âmirî, bu kişinin ibadetinin Allah, insanlar, melekler nezdinde kabul görmeyeceğini ifade etmektedir. ${ }^{50}$ Filozofun bu değerlendirmeleri açık bir şekilde göstermektedir ki dindar insanın erdemli olması, ibadetlerini samimi bir şekilde yerine getirmesine bağlanmaktadır. Kısacası, ibadetlerin ahlakı güzelleştirici olması gerekmekte ve bu da ibadetler bilinçli bir şekilde ihlasla gerçekleştirildiğinde mümkün olabilmektedir. Âmirî’nin insanı dini bir canlı olarak görmesi ve ihlaslı ibadet vurgusu dindarlığa bakışını yansıtıcı niteliktedir.

İbadetler meselesini detaylı bir şekilde işleyen İhvân-1 Safâ, öncelikli olarak emir ve yasakların nedeninden, peygamberlerin amaçlarının neler olduğundan bahsettikten sonra ibadetlerdeki gaye üzerinde durmaktadır. İhvân-1 Safâ'ya göre, Allah'ın inanan müminlere bazı şeyleri farz kılması ve bazılarını yasaklaması imtihan içindir. Nitekim bu farz kılınan ve yasaklanan şeyler, Allah'ın kullarını yükseltmek, en mükemmel hale getirmek ve son gayeye ulaştırmak üzere takdir ettiği sebeplerdir. ${ }^{51}$ Gönül doktorları olan peygamberler ile ilahi kanun koyucuların amaçları aynı olup madde denizine dalmış insanı oradan kurtarmak, oluş-bozuluş aleminin girdabından çıkarıp ona hakikî aleme ilişkin unuttuklarını hatırlatmaktır. ${ }^{52}$

48 Ebü'l-Hasan el-Âmirî, Kitabu'l-emed ale'l-ebed (Sonsuzluk Peşinde), ed. İlhan Kutluer, çev. Yakup Kara (İstanbul: Türkiye Yazma Eserler Kurumu Başkanlığı Yayınları, 2013), 68.

49 el-Âmirî, Kitabu'l-emed ale'l-ebed, 76.

50 el-Âmirî, Kitabu'l-emed ale'l-ebed, 96.

51 İhvân-1 Safâ, İhvân-ı Safâ Risâleleri, çev. Abdullah Kahraman vd. (İstanbul: Ayrıntı Yayınları, 2012), 1/235; İhvân-1 Safâ, Resâilü İhvâni 's-Safâ ve Hullâni'l-Vefâ (Kum: Mektebü'l-İ'lami'lİslamiyye, 2000), 1/345.

52 İhvân-1 Safâ, İhvân-ı Safâ Risâleleri, 2/111; İhvân-1 Safâ, Resâil, 2/141. 
İbadetlerin yerleri, zamanları, mekanları ve şekilleri farklı olsa da hepsinde gaye aynıdır. Hac örneğini veren İhvân-1 Safâ, uyanık kalp ve arınmış bir nefis ile düşünen, basiretli bir göz ile bakan kimsenin bu sembollerle bezenmiş bu ibadetteki gayeyi yani İbrahim Halilürrahman'ın neyi kastettiğini ve amacını idrak etmek suretiyle kalbinin hidayete ereceğini belirtmektedir. ${ }^{53}$ "Namaz, kötülük ve çirkinliklerden alıkoyar." ${ }^{\circ 4}$ ayeti üzerinden kuşların dilinden namazın gayesinin şu olduğu açıklanmaktadır: "Namaz, kalplerin nefret kirinden ve şüphe pisliğinden arınması, Yüce Allah'a halis bir niyetle yaklaşma, doğru itikat, iyiliği emretme kıblesine yönelme, müminlerin yararlarını gerçekleştirme/kıyam, düşmanlık ve kinden geri durma/kuud, tevazu ile eğilme/rüku ve secde etme, hilim, iyi kardeşlerle birlikte şahitlik etme/teşehhüt ve bilgisizlikten korunmaktır/teslimdir. Bu özel fiiller yerine getirilince namaz diye adlandırılır." ${ }^{55} \mathrm{Bu}$ değerlendirmede şekilsel olarak kılınan değil, içselleştirilen bir namaz tasavvuruna işaret edildiği söylenebilir.

Arif ile rahip arasında geçen bir konuşma örneğinde bu daha iyi anlaşılmaktadır. Nitekim burada ibadetlerini hakkıyla yerine getiren kimselerle hakiki dindarlığın profilinin çizildiğinden bahsedilebilir. Arif ve basiretli has kullar olarak nitelendirilen müminler, İhvân-1 Safầ nezdinde Allah'a karşı görevlerini sadakatle yerine getiren takva sahibi kimseler olup sürekli Allah'ı görüyormuşçasına yapıp-ettiklerinde kendilerini sorguya çekmektedirler. ${ }^{56}$ Rahibin, arifin “Allah'la olan ilişkin nasıldır?" sorusuna verdiği en kötü ilişki cevabı manidardır. Özellikle ibadetlerdeki külfete işaret eden rahip "Rabbimiz bize bedenlerimizi yormayı, nefislerimize eziyet etmeyi, gündüzleri oruç tutup geceleri ibadet etmeyi, tabiatımıza yerleşmiş olan arzuları terk etmeyi, baskın hevâya (nefsani arzulara) karşı çıkmayı, saldırgan düşmanla mücadele etmeyi, yaşamın zorluklarına razı olmayı, bela ve musibetlere sabretmeyi emretti. Bütün bunlarla birlikte, yolun uzunluğuna, şaşkınlık ve şüphelerin çokluğuna rağmen, öldükten sonra ahirette verilecek 'ertelenmiş' bir mükafat da vadetti.." ${ }^{57}$ diyerek kendi içinde bulunduğu durumu açıklamıştır. Rahibin, Allah'ın emirlerinin altında yatan nedeni kavrayamadığından dolayı emredilen bu ibadetleri sadece şekilsel olarak değerlendirdiği söylenebilir. Aynı soruyu rahip, arife sorduğunda aldığı cevap, hakikî dindarlığın nasıl olması gerektiği konusunda ipuçları içermektedir.

Allah'la olan ilişkisini ilişkilerin en güzeli olarak ifade eden arif, Allah'ın bütün kullarına yönelik olan nimet, ihsan ve iyilikleri, yaratılışındaki güzellikleri hatırlatıp

53 İhvân-1 Safâ, İhvân-ı Safâ Risâleleri, 2/111-112; İhvân-1 Safâ, Resâil, 2/142.

54 Ankebut 29/45

55 İhvân-1 Safâ, İhvân-ı Safâ Risâleleri, 2/228; İhvân-1 Safâ, Resâil, 2/328.

56 İhvân-1 Safâ, İhvân-ı Safâ Risâleleri, 1/231; İhvân-1 Safâ, Resâil, 1/338.

57 İhvân-1 Safâ, İhvân-ı Safâ Risâleleri, 1/231-232; İhvân-1 Safâ, Resâil, 1/338-339. 
dünya ve ahiret nimetlerinin kıyaslamasını yaparak açıklamaktadır. Kullarına bir lütuf olarak gönderilen peygamberler vasıtasıyla ahiret yolunu gören müminler için ibadetler bir ağırlık değildir. Nitekim arifin gözüyle ibadetler, bir bağış, nimet, izzet ve şeref olup kulun Allah'1 zikretmeye ehil olduğunu gösteren bir işarettir. ${ }^{58}$

İhvân-1 Safâ, kuşlar ile Iraklı bir İbrani arasında geçen bir münakaşayı dile getirmektedir. Kendisini efendi, kuşları ise köle olarak gören adama kuşların dilinden cevap vermektedir. Kuş, kendilerine farz olmayan ibadetlerden yola çıarak bu ibadetlerin kişide eksik olan ahlakî noksanlıkları gidermek, onu kötülük ve çirkinliklerden alıkoymak üzere farz kılındığını ifade etmektedir. Oruç ve namaz, gıybet, çirkin söz, laf taşıma, oyun ve eğlence gibi günahların bağışlanması için farz kılınmıştır. İbadetler bu günahlardan dolayı hastalanan nefislerin tedavisi için kullanılmaktadır. Zekat ve sadakaya gelince verme konusunda cimriliğin ve mal biriktirmenin, çalmanın önüne geçmek üzere farz kılınmıştır. Bayram ve cuma namazları ise ahlakın güzelleşmesi, yardımlaşmanın artması ve birbirinden uzaklaşan insanlar arasındaki dostluğu pekiştirmek üzere emredilmiştir. Nitekim bu vesileyle dostluk ve kardeşlik sayesinde sevgi bağları kuvvetlenecek ve bu da işlerin iyileşmesini sağlayacaktır. Bunun sonucu olarak ise iyileşen işler vesilesiyle ülkelerde iyilik hakim olacak, bu da alemin iyilik ve bekasını temin edecektir. ${ }^{59}$ Kuşların diliyle anlatılan ibadetlerdeki gayelerde ahlak vurgusu açık bir şekilde ortaya çıkmaktadır.

İhvân-1 Safâ'nın amel ve ahlakıyla samimi ve sadık mümin vurgusu ${ }^{60}$ dindarlık algısının iman temelinde amel ve ahlak bütünlüğünden oluştuğunu söylemeyi mümkün kılmaktadır. Ayrıca İhvân-1 Safâ'nın ibadetlere ilişkin detaylı değerlendirmeleri göstermektedir ki şekilsel ve sembolik ibadetlerin arkasındaki hikmeti kavramak gerekmektedir. Kuşların diliyle de ifade edildiği üzere ibadetler, nefsi kötülüklerden arındırıc1, ahlakı güzelleştirici, unutulan hakikî alemi hatırlatıcı, toplumsal düzeni tesis edici, iyiliğin hakim olmasını sağlayıcı olmalıdır. Bu şekilde yerine getirilen, ahlakî olgunlaşmayı sağlayıcı ibadetler ile hakikî dindarlık gerçekleştirilmiş olmakta ve Allah ile insan arasındaki ilişki en iyi düzeye getirilebilmektedir.

İbadetler konusunu detaylı bir şekilde işleyen filozoflardan bir diğeri de hiç kuşkusuz İbn Sînâ'dır. Filozof, peygamberin koyduğu yasaları ve insanlar arasındaki maslahatları gözetici şeyleri iyi bir şekilde düzenlemesinin gerekliliğine işaret etmektedir. Bunun da insanların Yaratan'1 ve ahireti bilmedeki devamlılıklarını sağlamakla gerçekleşebileceğini açıklamaktadır. Nitekim aralıklarla tekrarlanan bazı

58 İhvân-1 Safâ, İhvân-ı Safâ Risâleleri, 1/232-233; İhvân-1 Safâ, Resâil, 1/339-342.

59 İhvân-1 Safâ, İhvân-ı Safâ Risâleleri, 2/225-228; İhvân-1 Safâ, Resâil, 324-29.

60 İhvân-1 Safâ, İhvân-ı Safâ Risâleleri, 1/236; İhvân-1 Safâ, Resâil, 1/346. 
fiil ve ameller sayesinde, peygamber vefat ettikten sonra bile bu konuda insanlarda bir unutkanlığın hasıl olmasının önüne geçilmiş olmaktadır. ${ }^{61}$ Allah'a yakınlaştırıcı bu fiiller, farz kılınmış ibadetler olup bunlardan bazıları hareketlerle veya başka hareketlere sebep olmakla uyarıcı niteliği taşımaktadırlar. Namaz, harekete; oruç ise hareketsizliğe örnek olarak verilebilir. ${ }^{62}$ Ayrıca İbn Sînâ'ya göre peygamberlerin Allah'a ibadeti zorunlu k1lmaları ilahî inâyetin bir gereği olup ibadetlerin bu anlamda yasa ve şeriatın sürekliliğini sağlayıcı toplumsal boyutunun yanı sıra nefsin arınmasını sağlamak suretiyle Allah'a yaklaştırıcı bireysel boyutu da mevcuttur. ${ }^{63}$ Bu anlamda İbn Sînâ'nın, dinin devamını sağlama, ahlakı güzelleştirme, nefsi arındırma ve ebedi mutluluğu kazandırmadaki rollerine işaret ederek ibadetleri farklı açılardan temellendirdiği görülmektedir. ${ }^{64}$

İbn Sînâ nezdinde kanun koyucu vasıtasıyla adalete davetin sürekliliği ve bunun ibadetler aracılığıyla yinelenmesi; hikmet, rahmet ve nimetin bir göstergesidir. Mabud'u hatırlatıcı olan ibadetlerin tekrar edilmesiyle hatırda tutmanın sürekliliğini sağlanmak üzere farz kılınan ibadetlerin dünyada büyük yararı, ahirette ise mükafatı vardır. Bununla birlikte filozofa göre yüzlerini Allah'a çeviren ve her şeyi beklentisiz bir şekilde yapan arifler için ise özel bir menfaat söz konusudur. ${ }^{65}$ Ayrıca İbn Sînâ'nın arifleri ibadetler noktasında bir model olarak sunduğu, onları Allah'ı bilen ve nefsini arındırmış seçkin insanlar diye tasvir ettiği söylenebilir. Arif insan profili, bir anlamda ibadetlerle hedeflenen şeyin nasıl gerçekleşeceğinin, yani ibadetler aracılığıyla Tanrı-insan ilişkisinin mükemmel bir şekilde nasıl kurulacağının somut örneğini teşkil etmektedir. ${ }^{66}$

İbn Sînâ, "Ben cinleri ve insanları, ancak bana kulluk etsinler diye yarattım." ayetini yorumlamakta ve liya'büdün kelimesinin liya'rifun şeklinde tevile gerek olmadığını, ibadetin marifetullah, yani Allah'ı bilmek olduğunu dile getirmektedir. ${ }^{68}$

61 İbn Sînâ, Kitâbu'ş-şifâ Metafizik II, çev. Ekrem Demirli ve Ömer Türker (İstanbul: Litera Yayınc1l1k, 2005), 191.

62 İbn Sînâ, Kitâbu'ş-şifâ Metafizik II, 191-92.

63 İbn Sînâ, Kitâbu'ş-şifâ Metafizik II, 194; İbn Sînâ, en-Necât (Felsefenin Temel Konularl), çev. Kübra Şenel (İstanbul: Kabalcı Yayıncılık, 2013), 282.

64 Ayşe Sıdıka Oktay, “İbn Sînâ Düşüncesinde İbadet ve Tanrı-Alem İlişkisi Bakımından Değeri”, c. I (Uluslararası İbn Sînâ Sempozyumu Bildirileri, İstanbul: İstanbul Büyük Şehir Belediyesi Kültür A.Ş., 2008), 137.

65 İbn Sînâ, Işsaretler ve Tenbihler, 183-84.

66 Oktay, “İbn Sînâ Düşüncesinde İbadet”, 146-47.

67 Zariyât 51/56

68 İbn Sînâ, Namaz Hakkindaki Görüşleri, çev. M. Hazmi Tura (İstanbul: Bürhaneddin Matbaası, 1942), 15; İbn Sînâ, “el-Keşf an mahiyyeti's-salat ve hikmetu teşriiha: Mahiyyetü's-salat”, içinde Câmiü'lbedai': Yahtevi ala resâili'ş-Şeyh er-Reis İbn Sînâ (Beyrut: Darü'l-Kütübi'l-İlmiyye, 2004), 11. 
Ayeti bu şekilde yorumlayanlar, liya'büdûn diye nazil olmadaki ince manayı ise muteber olan ve istenen marifetullahın ibadetlerden husule gelmesi gerektiği şeklinde açıklamaktadırlar. ${ }^{69} \mathrm{Bu}$ bağlamda ibadet, beşeri şeylerden soyutlanmış, beşeriyetten kaynaklanan bulanıklıklardan uzaklaşmış, temiz bir kalp ile hak dışında bütün her şeyden ruhu azade etmek suretiyle Vacibu'l-Vücudu bilmek olarak tarif edilmektedir. ${ }^{70} \mathrm{Bu}$ anlamda namazın hakikati, Allah'ın varlığının kendi zatından ve bir olduğunu, zatı ve sıfatlarıyla her türlü noksanlıktan münezzeh olduğunu bilmek ve k1lınan namazı ihlas ile k1lmaktır. ${ }^{71}$

Namaz ibadetine ayrı bir önem veren İbn Sînâ, namaza dair detaylı bilgilendirmeye el-Keşf 'an Mâhiyyeti's-Salât ve Hikmetu Teşri'iha li İbn Sinâ adlı eserinde yer vermektedir. İbn Sînâ, namazı "ibadetlerin bir bakıma en üstünü, sahibine (kılana) Allah'a hitap eden, O’na yakaran, O’na yönelen ve önünde duran kimse olma zorunluluğunu yükleyen ibadet" 72 şeklinde açıklamaktadır. O, mahlukat içerisinde ilâhî hitaba ehil ve akil kılınanın insan oluşundan bahsettikten sonra bu risaleyi yazma gayesini zahirî olarak emredilen namaza ve onun asıl istenilen batınî yönüne işaret etmek şeklinde açıklamaktadır. ${ }^{73}$ Nitekim namazı, "(nefs-i nâtıka)nın ecramı felekiyyeye benzemesi ve ebedî; (sevab) talebi için (hakkı mutlak)a tapınması" "74 diye tarif etmektedir. Namazın dinin direği olduğuna dair hadisi aktaran İbn Sînâ'ya göre din, insanın şeytanî bulanıklıklardan, beşerî hatıralardan temizlemesinin yanı sıra, emel ve arzulardan, kötü garazlardan yüz çevirmesini sağlamaktadır. Namaz ise Yüce Mabud'a yani İlk İllet'e kulluk manasına gelmektedir. ${ }^{75}$

Namazı zahir ve batın olmak üzere iki kısma ayıran İbn Sînâ'ya göre zahirî namaz, imanın kökü ve kaidesi olarak görülen, şer'an kılınması farz, keyfiyeti açıklanmış, vakitleri belirli olan namazdır. Batınî namaza gelince filozof bunu, bütün arzulardan uzaklaşmış, temizlenmiş bir nefis ve halis, safî bir kalp ile hakk1 müşahede etmek diye tarif etmektedir. Nitekim Peygamber efendimizin "Namaz k1lan kimse Rabbine münacat eder yani Rabbine gizlice niyazda bulunur" 76 mealindeki hadisinde bahsedilen namazın da bu olduğunu söyleyen filozof, bunun cismanî uzuv ve hissi lisanla olamayacağını dile getirmektedir. ${ }^{77}$

692 nolu dipnota bkz. İbn Sînâ, Namaz, 15.

70 İbn Sînâ, Namaz, 15-16; İbn Sînâ, “el-Keşf an mahiyyeti’s-salat”, 11.

71 İbn Sînâ, Namaz, 16; İbn Sînâ, “el-Keşf an mahiyyeti’s-salat”, 11-12.

72 İbn Sînâ, Kitâbu'ş-şifâ Metafizik II, 192.

73 İbn Sînâ, Namaz, 5-6; İbn Sînâ, "el-Keşf an mahiyyeti’s-salat”, 7.

74 İbn Sînâ, Namaz, 14; İbn Sînâ, “el-Keşf an mahiyyeti's-salat”, 11.

75 İbn Sînâ, Namaz, 15; İbn Sînâ, “el-Keşf an mahiyyeti's-salat”, 11.

76 Buhârî, Salât, 33.

77 İbn Sînâ, Namaz, 17,19-20; İ̉n Sînâ, “el-Keşf an mahiyyeti's-salat”, 13-15. 
İbn Sînâ, namazın iki kısmı üzerinden Ankebut suresinin 45. ayetini bu bağlamda yorumlayarak namazın; zahiriyle bu alemde yaşadığ 1 zaman zarfında kişinin afetlerden korunmasını ve muhafaza edilmesini, özellikle batınî yönüyle ise Allah'ın birliğini bilen nefs-i nâtıkanın Rabbinden nefsini kemale erdirmesini ve saadetini tamamlamasını niyaz etmesi ve yalvarması olarak görmektedir. $O$, namazı bâtın-1 hakikîyle kılmayı başaran kimsenin hayvanî kuvvelerden, ona tabi olan şeylerden kurtulup aklî derecelere yükselebileceğini, ezelî sır ve manalara vakıf olabileceğini belirterek ayette işaret edilen namazın da bu olduğunu söylemektedir. ${ }^{78}$

Hem yüce hem de süfli alemden unsurlar taşıyan, yani nefs-i nâtıkası yanında bitkisel ve hayvanî nefisten müteşekkil olan insanın namaz ibadetine karşı göstereceği tembelliğin kabul edilemeyeceği ifade edilmektedir. Nitekim namaz, faal akıldan feyzin akmasını, azaptan korunmayı, bedenin arzularından kurtulmasını ve isteklerine ulaşmasını sağlamaktadır. Faal aklın feyzinden bu anlamda mahrum kalan kimse ise şerre ve fenalığa düşmekte ve yırtıcı hayvanlardan daha aşağı seviyeye inmektedir. Ancak arzu ve heveslerini aklın kontrolüne almayı başaran, ruhanî kuvvesini cismanî kuvvesi üzerine hakim kılan, süflî alemin meşguliyetlerinden ve takıntılarından sıyrılmayı başaran kimse hakikî kul olabilmektedir. İşte nefsi temiz ve pak olan bu kula hakikî, halis namaz şiddetle farz olmakta ve ibadetinde karşılaştığ1 güçlükler katlandığında o, en yüksek iyiliklere ve ahiretteki bütün saadetlere ulaşma imkanı bulmakta, yani iki dünyada da mutluluğa erişebilmektedir. Filozof, namazın zahirine karşı tembellik göstermemek ve batınını da ihmal etmemek gerektiğini dile getirmektedir. ${ }^{79}$

Her ibadetin övülmüş adap ve usûlünün yasa yapılması gerektiğine dikkatleri çeken filozof, bu fillerle amaçlanan; sıradan insanların Allah ve ahireti hatırlamaları, yasa ve şeriatlere uymayı sürdürmelerini sağlamaktır. İbadetler vesilesiyle kalıcı hale getirilen hatırlatmalar olmasaydı bunlar bir iki asır içerisinde unutulabilirdi. İbadetler sadece bir hatırlama değildir, aynı zamanda ahirette nefisleri arındırmada insanlara yardımcı olan fiillerdir. ${ }^{80}$ Bununla birlikte nefsi arındırmada halis niyetin önemine vurgu yapan İbn Sînâ, nefsin arzularını bastırmada bedeni ibadetlerin daha güçlü etkisinin olduğundan bahsetmektedir. Kısacası, kaba-hayvanî duyguların üstesinden gelmede nefse zor gelen dini ibadetlerin gerekliliği vurgulanmaktadır. Ayrıca dini hayata bağlılığını devam ettiren nefsin faziletlere ulaşıp melekleri andıracak bir düzeye erişebileceği düşünülmektedir. ${ }^{81}$

78 İbn Sînâ, Namaz, 22-24; İbn Sînâ, “el-Keşf an mahiyyeti's-salat”, 16.

79 İbn Sînâ, Namaz, 25-26; İ̉n Sînâ, “el-Keşf an mahiyyeti’s-salat”, 17.

80 İbn Sînâ, Kitâbu'ş-şifâ Metafizik II, 193.

81 İbn Sînâ, Mutluluk ve İnsan Nefsinin Cevher Olduğuna Dair On Delil (Risâle fi 's-se'âde ve'lhuceci'l-'aşere) (Ankara: Türkiye Diyanet Vakfı Yayınları, 2011), 95. 
İbadetler konusunda da amme ve hassa ayrımına giden filozofa göre seçkinlerin bu fiillerden yani ibadetlerden elde edecekleri faydanın büyük bir kısmı ahirettedir. Ahiretteki mutluluk, nefislerin arındırılmasıyla elde edilebilmekte, bu da ahlak ve melekeler vasitasıyla hasıl olmaktadır. Ahlak ve melekelerin elde edilmesi ise nefsin beden ve hislerden yüz çevirmesini sağlayan ve ona kaynağını hatırlatan fiiller sayesindedir. ${ }^{82}$

İbadetlerin mutluluğa ulaştırmadaki fonksiyonu üzerinde de duran İbn Sînâ, şunları söylemektedir: “Erdemlerin esası ve kökü; aziz ve celil olan Allah'ın ululuğunu uzun uzadıya düşünerek O'na dönmektir. Çünkü kim O'nu düşünürse; $\mathrm{O}$, yüce inâyetini onun üzerine seriverir. Sonra O'nun elçiliğini bize tebliğ etmiş ve dinini göstermiş, olan peygamberine saygı duymamızdır. Sonra da, onların getirmiş oldukları oruç, namaz ve sair iyi davranışlar gibi şeriata ilişkin eylemlere sarılmaktır. Çünkü bunlar, yüceliklerini Rabb'ına yaklaştıran ve O'nun katında makam elde ettiren davranışlardır ki, bu, mutluluğun zirvesidir." ${ }^{83}$ Kısacası, ebedî mutluluğun elde edilmesini, insanın dünya hayatındaki iyi ve güzel davranışlar ile Allah'ı bilme ve nefsi arındırmaya bağlayan İbn Sînâ, bunları gerçekleştirmede ibadetlerin önemli bir fonksiyon icra ettiğini ortaya koymakta, aynı zamanda Allah'ın neden kendisine ibadet etmemizi istediğini de açıklamaktadır. ${ }^{84}$

İbn Sînâ, ibadetler konusunu ayrıntılı bir şekilde incelemiş, ilahî hitaba mazhar olan insanın bu konuda tembellik göstermemesi gerektiğini belirtmiştir. İbadet etmenin bir anlamda Allah'1 bilmek olduğunu da vurgulayan filozof, zahirî ve batınî namaz ayrımıyla ibadetlerdeki iki boyutluluğa dikkatleri çekmektedir. Her iki yönü de ihmal etmeyerek hakikî namaz kılan kimsenin nefsini arındırıp mutluluğa erişebileceğini belirtmektedir. Özetle söylemek gerekirse İbn Sînâ da İhvân-1 Safâ gibi ibadetlerin hatırlatma ve şeriatın sürekliliğini sağlama yönüne işaret etmekte ve ahlakı güzelleştirici, nefsi arındırıcı olduğunu vurgulamaktadır.

Hüccetü'l-İslam olarak tanınan Gazzâlî'ye gelince o, ibadet etmeyi insanın, kendinden üstün olan bir varlığa bağlılığını göstermek üzere doğuştan kendisinde bulunan tabiî bir özellik olarak görmektedir. Allah'ın ibadetlerin nuru ile kalpleri imar ettiğinden ${ }^{85}$ ve ibadetlerden hedeflenen gayenin kalbe tesir edip onu düzeltmek

82 İbn Sînâ, Kitâbu'ş-şifâ Metafizik II, 193.

83 İbn Sînâ, “el-Ahlak”, içinde İbn Sînâ'nın Şimdiye Kadar Bilinmeyen Bir Ahlak Risalesi, çev. Bekir Karlığa (y.y., t.y.), ar.35, tr.81-82.

84 Oktay, “İbn Sînâ Düşüncesinde İbadet”, 138, 141.

85 Gazzâlî, İbadetlerin Ruhu (İhya'dan Seçmeler), çev. Muhammed Çoşkun, Timaş yayınları; 2987 (İstanbul: Timaş Yayınları, 2013), 11. 
olduğundan ${ }^{86}$ bahseden Gazzâlî, Allah'ın kullarının ibadetine ihtiyacı olmadığını dile getirmekte ve kullarını ibadetlerle mükellef kılmasının sebebini, onların ahlakını güzelleştirmek, onları affına ve mağfiretine yaklaştırmak, gazabından ve azabından uzak tutmak olduğunu açıklamaktadır. Ayrıca o, kulun ibadetlerini hakkıyla yerine getirdiğinde faydasını da o derece göreceğini söylemektedir. ${ }^{87}$ Bununla birlikte Gazzâlî, günah işleyip kirlenen bir kimsenin ibadetinin değerinin olmayacağını da hatırlatmaktadır. ${ }^{88}$

Düşünür, ibadetlerin yapılması gerekenler ve terkedilmesi, kaçınılması gerekenler olmak üzere ikiye ayrıldığını söylemektedir. İlk kısmına her türlü ibadet girerken; ikinci kısmı günahlardan kaçınmak, yani takva oluşturmaktadır. Bu anlamda ikinci kısmın öncelikli olduğuna dikkatleri çeken Gazzâlî, dinin özüne nüfuz edemeyenlerin bu birinci kısmı, dinin özünü kavrayanların ise ikinci kısmı gerçekleştirmeye çalıştıklarını ifade etmekte ve günahlardan el çekme manasına gelen ikinci kısmın daha mühim olduğunu dile getirmektedir. Her ikisini de bir arada toplamayı başaranın selamete ereceğini belirten düşünür, gecesini namazla gündüzünü oruçla geçiren kimse eğer ki insanları incitmeye devam ederse, yaptığı bu ibadetlerin ona bir faydası olamayacağına değinmektedir. ${ }^{89}$ Gazzâlî̀nin bu değerlendirmeleri ibadet-ahlak bütünlüğünün ne kadar önemli olduğuna bir işaret olarak görülebilir.

Gazzâlî’nin zahirî ve batınî amel tasnifi de dikkat çekicidir. O, bunların birbirine bağlı olduğunu dile getirmekte ve ihlas, riyâ, kendini beğenmişlik gibi, batınî amellerin zahirdeki ameller üzerinde etkili olduğunu ve onları 1slah edebileceği gibi bozabileceğine de işaret etmektedir. ${ }^{90}$ Ayrıca "günah işlemeye, zulmetmeye devam eden bir kimse nasıl Allah'a ibadet ettiğini söyleyebilir?"'1 diye sorarak ibadetlerin güzel davranışlarımızı artırıcı ve kötü davranışları yok edici olması gerektiğini vurgulamaktadır.

İbadetler, kişiyi hayvanî ve şehvanî arzulardan, azdırıcı ve saptırıcı duygulardan kurtarıp meleklik alemine yükselmesini sağlayan faydalara haizdir. İbadetin şuuruna varmış bireylerden teşekkül eden toplumda ilahî düzenin yansımasını görmek mümkündür ve bu toplulukta birlik, beraberlik, yardımlaşma ve fedakarlık gibi

86 Gazzâlî, İhyâ, 3/136.

87 Gazzâlî, Arifler Yolu (Minhacü'l-Arifin), çev. Yaman Arıkan (İstanbul: Elifbe Yayınları, 1981), $32-33$.

88 Gazzâlî, Abidler Yolu (Minhac'ül abidin), çev. Yaman Arıkan (İstanbul: Yaylacık Matbaası, 1968), 9.

89 Gazzâlî, Abidler Yolu, 127-28.

90 Gazzâlî, Abidler Yolu, 20.

91 Gazzâlî, Abidler Yolu, 28. 
güzel hasletler yaygındır. ${ }^{92}$ Tam bir şuurla, yani bilerek, anlayarak yapılan ibadet, kişinin ahlakını güzelleştirir. Kişide bu tarz bir dönüşümü gerçekleştirmeyen, yani ruhu temizlemeyen, kalbi yüceltmeyen ve ahlakı yükseltmeye katkısı olmayan ibadet, şuursuzca yapılan özel hareketten öteye geçmez, herhangi bir değeri ve önemi olmadığ 1 gibi, kutsal bir vazife olarak da addedilmez, bir adetten öteye geçemez. Ayrıca böylesi bir ibadetin kişiye hiçbir faydası olmaz ve bu başkalarını kandırmak için yapılan gösterişten başka bir şey değildir. Kime ve nasıl ibadet etmesi gerektiği bilincinde olan insan için ibadetler, ahlakı güzelleştirici bir fonksiyon icra etmektedir. ${ }^{93}$

İbadetlerin kişisel ve sosyal faydaları sağlayıc ilahi hikmetler içerdiğini söyleyen Gazzâlî, ibadetlerde insanları selamete, saadete ve insanca yaşamanın mutluluğuna ulaştırmak üzere hem kişiyi hem de toplumu maddî ve manevî kirlerden arındırma amac1 güdüldüğünü ifade etmektedir. ${ }^{94}$ Ayrıca 0 , her ibadetin bir zahirî bir de batın̂̂ yönünün, yani kabuk ve özünün varlığına işaret etmekte ${ }^{95}$ ve insanın ibadetin özünü ihmal etmemesinin gerekliliğini vurgulamaktadır. İbadetlerin içselleştirilmesi, amacına ulaşması için ahlakı güzelleştirici olması gerektiğini vurgulayarak Gazzâlî, gösterişçi dindarlık ile hakikî dindarlığın ayırıcı noktasına da işaret etmiş olmaktadır.

\section{Sonuç}

Dindarlık kavramı tanımlanması çok güç bir kavram olarak karşımıza çıkmaktadır. $\mathrm{Bu}$ güçlüğe rağmen farklı disiplinler, bu kavramı kendi bakış açıkları ekseninde açıklamaya çalışmışlardır. Dindarlığın inanç, ibadet, ahlak olmak üzere üç boyutundan bahsetmek mümkün görünmektedir. Bu üç boyutun hiçbirinin ihmal edilmemesi gerekmektedir. İbadetler, en çok göz önünde bulundurulan ve dindarlığın yansımasının somut örnekleri arasında görülen boyutu teşkil etmektedir. Gerçekşekilsel, tahkiki-taklidi, ihlasl1-gösterişli, iç güdümlü-dış güdümlü dindarlık ayrımlarında ibadetlerin belirleyici bir fonksiyona sahip olduğunu söylemek mümkündür.

Dinin emrettiği ibadetlerdeki asıl gayenin göz ardı edilmemesi gerekmektedir. Nitekim şekilsel olarak gerçekleştirilen ve birçok sembolik yönü olan ibadetlerin insanın ahlakını güzelleştirmesinin gerekliliği İslam düşünürleri tarafından açıkça dile getirilmiştir. İnsanı dini bir canlı olarak ifade eden Âmirî, erdemli olmayı

92 Gazzâlî, Büyük İslam Dini: Iman Prensipleri İslam Düşüncesi ve Ahlakl, çev. Abdullah Aydın (İstanbul: Dilek Matbaas1, t.y.), 187.

93 Gazzâlî, Büyük İslam Dini, 188.

94 Gazzâlî, Büyük İslam Dini, 190.

95 Gazzâlî, İbadetlerin Ruhu, 106. 
ibadetleri bilinçli ve ihlaslı bir şekilde yerine getirmeye bağlamaktadır. İhvân-1 Safâ'ya göre ise dini emir ve yasaklar bir hatırlatma, insanı yüceltme, son gayeye ulaştırma amacını taşımaktadır. İbadetlere gelince sadece şekilsel olarak değil, özümsenerek gerçekleştirilmesi gerekmektedir. Aksi takdirde ibadetler, bir külfet olarak görülüp Allah-insan arasındaki ilişki doğru bir şekilde kurulamaz. Nitekim İhvân-1 Safâ, ibadetlerin farz kılınış gayesinin kişideki ahlaki noksanlıkları giderme, onu kötülüklerden uzaklaştırma olduğuna dikkati çekmekte ve bunun da ancak samimi bir şekilde yerine getirildiğinde mümkün olabileceğini ifade etmektedir. Dindar insan, arif profilinde olduğu üzere, sadık bir mümin olup ibadetleri bilinçli bir şekilde yerine getiren ve bu vesileyle de ahlakî olgunluğunu en üst seviyeye çıkarmaya çalışan kimse olarak karşımızda durmaktadır.

İbn Sînâ’nın ibadetlerin dinin devamlılığını sağlayıcı, nefsi arındırıcı, ahlakı güzelleştirici fonksiyonları üzerinden bir dindarlık anlayışı ortaya koyduğundan bahsedilebilir. Ondaki ibadetleri herhangi bir menfaat beklemeksizin gerçekleştiren ve ahlakî olgunluğa erişmiş olan "arif insan” profili, samimi, içselleştirilmiş dindarlı̆̆ın nasıllığına güzel bir örnektir.

Gazzâlî’ye gelindiğinde o, insanın ibadetle mükellef kılınmasının sebebinin ahlakını güzelleştirmek, Allah'ın rahmetine erişip gazabından korunmak olduğunu ifade etmektedir. Şuursuzca yapılan bir ibadetin insana hiçbir faydasının olmayacağına da işaret eden düşünür, ibadetlerin ahlakı güzelleştirmesi gerektiğini vurgulamaktadır.

İbadetlerdeki asıl amacın insanın kendi özüne yönelmesi, onda potansiyel olarak bulunan ve Fârâbî’nin “doğal erdem” adını verdiği niteliğin ortaya çıkmasını sağlamak olduğu unutulmamalıdır. Bu anlamda dini ritüellerin, Allah'a ulaşmayı, ebedî mutluluğa erişmeyi sağlayıcı yönlerinin gün yüzüne çıkarılması gerekmektedir. $\mathrm{Bu}$ anlamda ibadetler bir araç olup, amaç kişinin kendini tanımak, iyi yönlerini artırmak, kötü yönlerini törpülemek suretiyle Allah'a yönelmesidir. Bunun idrakine varamayanlar için ibadetler, maalesef ki belirli hareketlerle sınırlı kalacak, bireyde bir değişim ve dönüşüm gerçekleştiremeyecektir.

Sonuç olarak İslam düşünürleri nezdinde ibadetlerin, samimi ve ihlaslı dindar olabilmenin olmazsa olmazlarından olduğu söylenebilir. Ancak sadece şekilsel olarak gerçekleştirilen ibadetlerin insana hiçbir faydası olmayacağı da unutulmamalıdır. İbadetlerin ahlakı güzelleştirmesi, insanı kötülüklerden koruması gerekmektedir. Samimiyetle, ihlasla ve hakkını vererek yerine getirilen ibadetler, kişiye hem Allah ile en üst düzeyde iyi bir ilişki kurma şansını hem ebedi mutluluğa erişme imkanını sunmaktadır. Kısacası, hakikî dindarlık, iman, ibadet ve ahlak üçlüsünün bir insanda bir araya gelmesiyle hayat bulabilir. İslam düşünürlerinin ibadet vurguları 
da göstermektedir ki samimi dindarlığın vazgeçilmez unsurları arasında ahlakı besleyici ibadetler yer almaktadır.

İslam düşünürlerinin ısrarla vurguladıkları ve arif insan profili ile somutlaştırdıkları samimi dindarlık toplumda yaygınlaştırılmalıdır. Dinin emir ve yasakları öğretilirken ibadetlerin şekilsel yönlerinin yanı sıra, ibadetlerle amaçlanan en önemli şeylerden birinin ahlakı güzelleştirmek olduğu gerçeğinin üzerinde çokça durulmalı ve insanlar, ibadetlerini bilinçli bir şekilde yerine getirmeye teşvik edilmelidir.

Hakem Değerlendirmesi: Dış bağımsız.

Çıkar Çatışması: Yazar çıkar çatışması bildirmemiştir.

Finansal Destek: Yazar bu çalışma için finansal destek almadığını beyan etmiştir.

Peer-review: Externally peer-reviewed.

Conflict of Interest: The author has no conflict of interest to declare.

Grant Support: The author declared that this study has received no financial support.

\section{Kaynakça/References}

Âmirî, Ebü'l-Hasan el-. Kitabu'l-emed ale'l-ebed (Sonsuzluk Peşinde). Editör İlhan Kutluer. Çeviren Yakup Kara. İstanbul: Türkiye Yazma Eserler Kurumu Başkanlığı Yayınları, 2013.

Ayten, Ali. Empati ve Din: Türkiye'de Yardımlaşma ve Dindarlı Üzerine Psiko-sosyal Bir Araştırma. İstanbul: İz Yayınc1lık, 2010.

Baynal, Fatma. “Türkiye'de Dindarlık Üzerine Kullanılan Ölçeklere Yönelik Sorunlar ve Öneriler”. İçinde Din Psikolojisi Güncel Durum Analizi, 263-86. Ankara: Nobel Akademik Yayınc1lık, 2020.

Cirhinlioğlu, Zafer, Üzeyir Ok, ve Fatma Gül Cirhinlioğlu. Dindarlık Ruh Sağlığ ve Modernite. Ankara: Nobel Akademik Yayıncılık, 2013.

Fârâbî. "Fusûlü'l-medenî (Siyaset Felsefesine Dair Görüşler)". İçinde Fârâbî'nin İki Eseri, çeviren Hanifi Özcan, 45-138. İstanbul: Marmara Üniversitesi İlahiyat Fakültesi Vakfi, 2005.

. "Mutluluğu Kazanma (Tahsilu's-Sa'ade)". Içinde Farabi'nin Üç Eseri, çeviren Hüseyin Atay. İstanbul: Morpa Kültür Yayınları, 2008.

Gazzâlî. Abidler Yolu (Minhac'ül abidin). Çeviren Yaman Arıkan. İstanbul: Yaylacık Matbaası, 1968. - Arifler Yolu (Minhacü 'l-Arifin). Çeviren Yaman Arıkan. İstanbul: Elifbe Yayınları, 1981.

Büyük İslam Dini: Iman Prensipleri İslam Düşüncesi ve Ahlakl. Çeviren Abdullah Aydın. İstanbul: Dilek Matbaası, t.y.

İbadetlerin Ruhu (Ihyya'dan Seçmeler). Çeviren Muhammed Çoşkun. Timaş yayınları; 2987. İstanbul: Timaş Yayınları, 2013.

İhyâu ulûmi'd-dîn. Çeviren Ahmet Serdaroğlu. 1-4 c. İstanbul: Bedir Yayınevi, 2002.

Güler, İlhami. ““Vicdansız Dindarlık’ Olarak Güncel Müslümanlık”. İslami Analiz. Erişim 20 Şubat 2020. http://www.islamianaliz.com/m/3500/vicdansiz-dindarlik-olarak-guncel-muslumanlik.

Günay, Enver. "Dindarlığın Sosyolojisi”. İçinde Dindarlığın Sosyo-Psikolojisi, editör Enver Günay ve Celaleddin Çelik, 1-59. Adana: Karahan Kitabevi, 2006. 
Gündüz, Şinasi. Din ve İnanç Sözlüğü. Ankara: Vadi Yayınları, 1998.

Gürses, İbrahim. Dindarlık ve Kişilik. Bursa: Emin Yayınları, 2010.

Hökelekli, Hayati. Din Psikolojisi. Ankara: Türkiye Diyanet Vakfı Yayınları, 2004.

İbn Sînâ. "el-Ahlak”. İçinde İbn Sînâ'nın Şimdiye Kadar Bilinmeyen Bir Ahlak Risalesi, çeviren Bekir Karlı̆̆a. y.y., t.y.

_. "el-Keşf an mahiyyeti's-salat ve hikmetu teşriiha: Mahiyyetü’s-salat". İçinde Câmiü'lbedai': Yahtevi ala resâili 'ş-Şeyh er-Reis İbn Sînâ, 7-12. Beyrut: Darü'l-Kütübi'l-İlmiyye, 2004. 2013.

en-Necât (Felsefenin Temel Konuları). Çeviren Kübra Şenel. İstanbul: Kabalcı Yayıncılık,

- IŞaretler ve Tenbihler (el-i̧̇ârât ve't-tenbîhât). Çeviren Ali Durusoy, Muhittin Macit, ve Ekrem Demirli. İstanbul: Litera Yayınc1lık, 2005.

—. Kitâbu'ş-şifâ Metafizik II. Çeviren Ekrem Demirli ve Ömer Türker. İstanbul: Litera Yayıncılık, 2005.

—.Mutluluk ve İnsan Nefsinin Cevher Olduğuna Dair On Delil (Risâle fi's-se'âde ve'l-huceci'l'aşere). Ankara: Türkiye Diyanet Vakfı Yayınları, 2011.

—. Namaz Hakkındaki Görüşleri. Çeviren M. Hazmi Tura. İstanbul: Bürhaneddin Matbaası, 1942.

İhvân-1 Safâ. İhvân-ı Safâ Risâleleri. Çeviren Abdullah Kahraman, İsmail Çalışkan, Enver Uysal, Ali Avcu, Murat Demirkol, Kamuran Gökdağ, ve Elmin Aliyev. 1-5 c. İstanbul: Ayrıntı Yayınları, 2012.

—. Resâilü İhvâni 's-Safâ ve Hullâni'l-Vefâ. 4 c. Kum: Mektebü'l-İ'lami'l-İslamiyye, 2000.

Kayıklık, Hasan. Din Psikolojisi: Bireysel Dindarlık Üzerine. Adana: Karahan Yayınları, 2011.

Kirman, Mehmet Ali. Din Sosyolojisi Sözlüğ̈̈. Adana: Karahan Kitabevi, 2016.

Mehmedoğlu, Ali Ulvi. Kişilikve Dindarlık (Dindarlık Düzeyi ile Kişilik Özellikleri Arasındaki İlişki Üzerine Bir Araştırma). İstanbul: Değerler Eğitim Merkezi Yayınları, 2004.

Oktay, Ayşe Sıdıka. "İbn Sînâ Düşüncesinde İbadet ve Tanrı-Alem İlişkisi Bakımından Değeri”, I:133-48. İstanbul: İstanbul Büyük Şehir Belediyesi Kültür A.Ş., 2008.

Okumuş, Ejder. Gösterişşi Dindarlık. İstanbul: Ark Kitapları, 2005.

Öztürk, Mustafa. "Bilgi-Ahlâk-Dindarlık”. Diyanet Aylık Dergi, sy Ağustos (2007): 5-7.

Serinsu, Ahmet Nedim, ed. Dini Terimler Sözlüğü. Ankara: Milli Eğitim Bakanlığı Yayınları, 2009.

Seyyar, Ali. Insan ve Toplum Bilimleri Terimleri (Ansiklopedik Sosyal Bilimler Sözlüğü). İstanbul: Değişim Yayınları, 2007.

Subaşı, Necdet. “Türk(iye) Dindarlığı: Yeni Tipolojiler”. İslâmiyât V, sy 4 (2002): 17-40.

Taş, Kemaleddin. "Dindarlı̆̆ın Kriterleri Üzerine Tipolojik Bir Araştırma”. İçinde Dindarlığın SosyoPsikolojisi, editör Enver Günay ve Celaleddin Çelik, 175-206. Adana: Karahan Kitabevi, 2006.

Topuz, İlhan. "Gazali’de Dini Tutum ve Davranışlar -Dini Yaşam Biçimleri-”. Marife Dini Araştırmalar Dergisi 11, sy 2 (2011): 157-77.

Turan, Yahya. Kişilik ve Dindarlık. İstanbul: Ensar Neşriyat, 2017.

Uysal, Enver. "Dindarlığın Ahlâkî Temeli Üzerine Bazı Düşünceler”. Uludağ Üniversitesi İlahiyat Fakültesi Dergisi 14, sy 1 (2005): 41-59.

Yapıcı, Asım. Ruh Sağlığı ve Din: Psiko-sosyal Uyum ve Dindarlık. Adana: Karahan Kitabevi, 2007. 